ks. Jan Dziedzic ${ }^{1}$

ORCID: 0000-0002-7229-8657; jan.dziedzic@upjp2.edu.pl

Uniwersytet Papieski Jana Pawła II w Krakowie

\title{
Kontekst pastoralny śmierci dziecka przed urodzeniem
}

\section{Streszczenie}

Strata dziecka martwo urodzonego jest bardzo dotkliwa. Odchodzi bowiem dziecko, z którym rodzice wiązali swoją przyszłość. Pojawia się także poczucie winy związane z odpowiedzialnością za zaistniałą sytuację. Rodzice przeżywający żałobę potrzebują często wsparcia ze strony otoczenia i Kościoła. W towarzyszeniu w żałobie ważne są: obecność, aktywne słuchanie, praktyczna pomoc.

Pogrzeb dziecka martwo urodzonego jest możliwy w Kościele, mimo to nie zostało ono ochrzczone. Białe szaty liturgiczne symbolizują niewinność dziecka, a sprawowana Eucharystia za rodziców pogrążonych w żałobie daje im nadzieję, że ich dziecko jest w rękach Boga.

Słowa kluczowe: dziecko martwo urodzone, żałoba, życie wieczne, pogrzeb

\section{Abstract}

The Pastoral Context of the Child's Death Before Birth

The loss of a stillborn child is very serious. Parents future disappears together with the departure of the child. There is also a sense of guilt associated with their responsibility for the arisen situation. Mourning parents often need support from their closests and the Church. Supportive presence, active listening, and practical help are very important during their mourning.

The funeral of a stillborn child in accordance to Church's rules is still possible despite the fact that the child has not been baptized yet. The white vestments symbolize

1 Ks. Jan Dziedzic - dr hab., prof. UPJPII, dziekan Wydziału Teologicznego Uniwersytetu Papieskiego Jana Pawła II w Krakowie, kierownik Uniwersytetu Trzeciego Wieku przy UPJPII. Koordynuje międzynarodową współpracę naukową i wymianę studentów z Uniwersytetem Ruhry w Bochum. Jest autorem kilkudziesięciu artykułów i kilku książek. Jego badania naukowe koncentrują się wokół teologii i psychologii pastoralnej oraz tanatologii. 
the child's innocence and the Eucharist celebrated for mourning parents gives them hope that their child is in God's hands.

Keywords: stillborn child, mourning, eternal life, funeral

Zjawisko niepowodzeń prokreacyjnych dotyczy około 15-20\% populacji kobiet w wieku rozrodczym. W Polsce odnotowuje się ponad 40 tys. roniących kobiet rocznie. Problem straty dziecka poronionego i martwo urodzonego jest w naszym społeczeństwie bagatelizowany i pomniejszany. Wynika to stąd, że strata nastąpiła w bardzo wczesnym okresie ciąży i zakłada się, że dotyczy znikomej części ludzi².

Dla matki i ojca poronienie i śmierć dziecka są bardzo dotkliwe. Zazwyczaj oczekują oni na narodziny dziecka, przygotowują się do nowych zadań związanych powiększeniem się rodziny. Po nagłej śmierci dziecka nastąpuje radykalna zmiana. Radość i oczekiwanie przemieniają się nagle w smutek i niedowierzanie. Osieroceni rodzice często stawiają pytanie, dlaczego nas to spotkało? W tej trudnej sytuacji potrzebują pomocy. Aby jej udzielić należy poznać wielowymiarowy kontekst straty, który wiąże się z poronieniem i śmiercią dziecka.

Tenże artykuł ma przybliżyć czytelnikowi problematykę straty dziecka martwo urodzonego i udzielić podstawowych informacji osobom bliskim i duszpasterzom, które są nieodzowne do udzielenia pomocy osobom przeżywającym żałobę 3 . W tym celu omówimy poniżej następujące zagadnienia: 1) Dziecko martwo urodzone, 2) Rodzina po śmierci dziecka poczętego, 3) Nadzieja zbawienia dla dzieci zmarłych bez chrztu, 4) Pogrzeb dziecka martwo urodzonego, 5) Towarzyszenie osieroconym po śmierci dziecka.

2 Por. A. Bubiak, J.Bartnicki, Z. Knihinicka-Mercik, Psychologiczne aspekty utraty dziecka w okresie prenatalnym, „Pielęgniarstwo i Zdrowie Publiczne” 4 (2014) nr 1, s. 70.

3 Prezentowany artykuł nawiązuje do badań prowadzonych od kilku lat w UPJPII w Krakowie: por. Od bólu po stracie do nadziei życia. Pogrzeb dziecka poronionego, red. J. Dziedzic, P. Guzdek, Kraków 2013; J. Dziedzic, Beistand bei Trauer. Psychologisch-pastorale Aspekte, „Polonia Sacra” 18 (2014) nr 2 (35), s. 51-74; „Polonia Sacra” 17 (2013) nr 1 (32) temat zeszytu: Dziecko poczęte. 


\section{Dziecko martwo urodzone}

Śmierć dziecka może nastąpić w różnych stadiach rozwoju życia. Jest to poronienie, poród martwego dziecka, śmierć noworodka i zespół nagłego zgonu niemowląt (SIDS) ${ }^{4}$. W rozporządzeniu Ministra Zdrowia z dnia 6 kwietnia 2020 roku czytamy, że

urodzenie martwe to całkowite wydalenie lub wydobycie z ustroju matki płodu, o ile nastąpiło po upływie 22 tygodnia ciąży, który po takim wydaleniu lub wydobyciu nie oddycha ani nie wykazuje żadnego innego znaku życia, jak: czynność serca, tętnienie pępowiny lub wyraźne skurcze mięśni zależnych od woli ${ }^{5}$.

Trzeba podkreślić, że zmarłemu ciału dziecka w początkowym stadium rozwoju należy się taki sam szacunek jak zwłokom osób dorosłych. Kongregacja Doktryny Wiary naucza, iż „zwłoki embrionów lub płodów ludzkich [...] powinny być uszanowane tak jak zwłoki innych istot ludzkich $[\ldots]^{6}$. W podobny sposób wypowiada się Papieska Rada do spraw Duszpasterstwa Służby Zdrowia. W Karcie Pracowników Służby Zdrowia stwierdza, że „płodowi już martwemu należy się szacunek właściwy każdemu zmarłemu człowiekowi"'. Żywy zarodek ludzki we wczesnych stadiach też jest kimś, a nie czymśs, dlatego po śmierci jego zwłoki wymagają takiego samego szacunku jak ciała innych zmarłych osób?.

Jedną z różnic, jaka istnieje między osobami a zwłokami ludzkimi jest ta, że osobom przysługują pełne prawa, a zwłokom tylko niektóre z tych

4 Por. H. Lothrop, Gute Hoffnung, jähes Ende, München 2016, s. 30.

5 Załącznik nr 1 do rozporządzenia Ministra Zdrowia z dnia 6 kwietnia 2020 roku w sprawie rodzajów, zakresu i wzorów dokumentacji medycznej oraz sposobu jej przetwarzania (Dz. U. z 2020, poz. 666).

6 Kongregacja Nauki Wiary, Donum vitae, Instrukcja o szacunku dla rodzącego się życia ludzkiego i godności jego przekazywania, 22.02.1987, nr 1, 4, w: W trosce o życie. Wybrane dokumenty Stolicy Apostolskiej, red. K. Szczygieł, Tarnów 1998, s. 360-385.

7 Papieska Rada do spraw Duszpasterstwa Służby Zdrowia, Karcie Pracowników Służby Zdrowia, Watykan 1995, nr 146, w: W trosce o życie. Wybrane dokumenty Stolicy Apostolskiej, red. K. Szczygieł, Tarnów 1998, s. 549-627.

8 Por. T. Biesaga, Spór o moralny status człowieka w okresie prenatalnym, „Medycyna Praktyczna - Ginekologia i Położnictwo" 6 (2006), s. 4.

9 Por. J. Dziedzic, Żałoba po śmierci Jana Pawła II. Analiza ilościowo-jakościowa Księgi kondolencyjnej. Internauci w hołdzie papieżowi Janowi Pawłowi II, Kraków 2009, s. 24. 
praw. Mówi się tutaj o prawie do szacunku czy prawie do uwzględnienia ostatniej woli zmarłej osoby ${ }^{10}$. Szacunek dla zmarłych jest wynikiem respektu, jakim winniśmy otaczać każdego bez wyjątku człowieka, ponieważ każdy został stworzony na obraz i podobieństwo Boga.

Zwłoki ludzkie nie mogą więc być traktowane tak jak przedmiot. Istnieje bowiem więź między osobą a jej martwym ciałem. Zwłoki nie będąc człowiekiem, pozostają jego znakiem, dlatego tradycja i obyczaj zobowiązują do szacunku wobec zwłok ${ }^{11}$. Przykładem wielkiego szacunku, jakim Kościół otacza ludzkie ciało, także po śmierci, jest obrzęd okadzenia zwłok podczas pogrzebu. Celebrans wypowiada wtedy słowa: „Twoje ciało było świątynią Ducha Świętego. Niech Bóg przyjmie cię do swojej chwały"12. O zwłokach ludzkich Katechizm Kościoła katolickiego mówi, że należy je pochować w ziemi jako „zasiew ciała, które zmartwychwstanie w chwale" (KKK 1683).

\section{Rodzina po śmierci dziecka poczętego}

Strata dziecka jest dla rodziców bardzo trudnym doświadczeniem. Często czują się oni winni śmierci swojego dziecka, pojawia się u nich także żal, że taka sytuacja przydarzyła się właśnie im ${ }^{13}$. Małe dziecko, które umiera, wydaje się umierać bez opowieści, bez miejsca we wspólnocie i bez czasu na dojście do pełnej osobowości jako osoba zdolna do dokonywania wyborów ${ }^{14}$. Najbardziej boli śmierć kogoś, z kim nie zdążyliśmy się jeszcze przywitać. W takiej sytuacji są rodzice, którzy utracili dziecko na skutek poronienia lub martwego urodzenia. Doświadczają oni bólu

10 Por. J. Bremer, Szacunek wobec ludzkich zwłok. Spojrzenie filozoficzno-prawne, w: Pedagogiczna refleksja nad życiem i śmiercia, red. B. Grochmal-Bach, https://opoka.org.pl/ biblioteka/I/ID/wam_2013_smierc_01.html (3.11.2020).

11 J. Meller, Moralny aspekt wykorzystania zwłok ludzkich, „Studia Gdańskie” 21 (2007), s. $431-433$.

12 Obrzędy pogrzebu dostosowane do zwyczajów diecezji polskich, wyd. 2, Katowice 2005, nr 65.

13 Por. M. Guzewicz, Psychologiczne i społeczne konsekwencje utraty dziecka w wyniku poronienia, „Civitas et Lex” 1 (2014), s. 17.

14 J.A. Thompson, Making room for the other: maternal mourning and eschatological hope, „Modern Theology” 27 (2011) Issue 3, s. 399. 
rozstania z kimś, kogo twarz, talenty czy radość życia mogą sobie jedynie wyobrażać ${ }^{15}$.

U wielu kobiet martwe urodzenie dziecka wywołuje kryzys. Niektóre z nich zdradzają objawy lękowe, a czasem dotyka je depresja ${ }^{16}$. Większość kobiet po stracie dziecka odczuwa poczucie winy i niepokój ${ }^{17}$. Główną konsekwencją pojawiającą się po stracie dziecka martwo urodzonego jest wysokie zagrożenie dla kolejnego dziecka ${ }^{18}$. Jeżeli poronienie nastąpiło przy pierwszej ciąży, rodzi się pytanie, czy kiedykolwiek będzie szansa, aby urodzić jeszcze dziecko ${ }^{19}$. Kobieta po stracie dziecka martwo urodzonego może mieć psychiczne trudności z ponownym zajściem w ciążę, zwłaszcza gdy planowanie ciąży odbywa się wcześniej niż rok po stracie ${ }^{20}$.

Chociaż w ogromnej większości przypadków kobiety, które poroniły, nie są moralnie winne. Zdarzają się jednak sytuacje, w których często czują się moralnie odpowiedzialne za śmierć swojego płodu. Kobieta ma poczucie winy, ponieważ zawiodła i nie potrafiła urodzić dziecka. Bierze się pod uwagę efekt końcowy, a mianowicie utratę ciąży. Nawet jeśli jest to kwestia nieprawidłowości chromosomalnych, kobieta w ciąży jest przynajmniej pośrednio powiązana ze stratą dziecka. To, że potencjalna matka będąca w stanie błogosławionym nie ma intencji dokonania aborcji, to w rzeczywistości pożądany przez nią cel urodzenia dziecka nie nastąpił, a zrealizował się w dokładnie odwrotnym stanie rzeczy ${ }^{21}$.

Kobiety po poronieniu czują też, że zawiodły zarówno w sensie etycznym, jak i emocjonalnym lub psychologicznym. W jakiś sposób zawiodły

15 M. Dziewiecki, Jak wspierać matkę po poronieniu dziecka?, https://glosdlazycia.pl/ wydanie/w-numerze/jak-wspierac-matke-po-poronieniu-dziecka/ Głos dla Życia 2011/6, S. $16(3.11 .2020)$.

16 S.S. Bansen, H.A. Stevens, Women's experiences of miscarriage in early pregnancy, ,Journal of Nurse Midwifery" 37 (1992), s. 84-90.

17 N. Brier, Understanding and managing the emotional reactions to a miscarriage, „Obstetrics Gynecology" 93 (1999), s. 151-155.

18 Por. M. Guzewicz, Psychologiczne i społeczne konsekwencje utraty dziecka w wyniku poronienia, „Civitas et Lex” 1 (2014), s. 18.

19 Por. J.W. Worden, Beratung und Therapie in Trauerfallen, Bern 1986/1999, s. 113-114.

20 Por. M. Guzewicz, Psychologiczne i społeczne konsekwencje utraty dziecka w wyniku poronienia, „Civitas et Lex” 1 (2014), s. 18.

21 S. Clark Miller, The Moral Meanings of Miscarriage, "Journal of Social Philosophy" 46 (2015) Issue 1, s. 146. 
rozwijający się w nich płód. Ponadto mogą odczuwać, że rozczarowały innych, którzy zainwestowali w ciążę. Kobieta nie może również ufać już swoim kompetencjom jako przyszła matka. Poronienie lub martwe urodzenie sprawiło, że zawiodła samą siebie ${ }^{22}$.

Obecnie rodzice spotykają się z wieloma problemami w obliczu poronienia i śmierci swojego dziecka. Najpierw jest to jakby nieuznawanie tego faktu przez społeczeństwo. Poronienia i martwe urodzenia dziecka są ukrywane i traktowane inaczej niż śmierć osoby dorosłej. Otoczenie często nie rozumie sytuacji rodziny po stracie dziecka. W czasie przeżywania żałoby pojawia się też kryzys rodziny, dotkniętej tak dotkliwym cierpieniem.

Nawet dziś zdarzają się przypadki krzywdzących komentarzy wobec rodziców. Mówi się do nich: „to była tylko ciąża trzymiesięczna, to nie było nawet dziecko”, „zawsze można mieć kolejne”, „lepiej było stracić dziecko teraz niż później”. Te komentarze nie tylko bolą rodziców i dowodzą o braku wsparcia, ale także mogą hamować gojenie się ran, związanych ze stratą dziecka, i powodują utratę zaufania pacjentów do służby zdrowia ${ }^{23}$.

Strata dziecka martwo urodzonego jest przeżyciem bardzo trudnym, które wyzwala różnorodne konsekwencje w szerokim kontekście funkcjonowania kobiety oraz jej rodziny. Bardzo ważne jest indywidualne traktowanie każdej z matek oraz ich rodzin ${ }^{24}$. Powinni to wiedzieć wszyscy towarzyszący, niezależnie od tego, czy są to lekarze, krewni, czy duszpasterze.

\section{Nadzieja zbawienia dla dzieci zmarłych bez chrztu}

Rodzice dzieci martwo urodzonych często pytają o los ich dzieci po śmierci. Wiadomo, że dzieci te zmarły bez chrztu, więc pytanie dotyczy

22 S. Clark Miller, The Moral Meanings of Miscarriage, s. 149.

${ }^{23}$ M. DiMarco, P. Renker, J. Medas, H. Bertosa, J.L. Goranitis, Effects of an Educational Bereavement Program on Health Care Professionals' Perceptions of Perinatal Loss, „Journal of Continuing Education in Nursing" 33 (2002) Issue 4, s. 180-181.

24 Por. M. Guzewicz, Psychologiczne i społeczne konsekwencje utraty dziecka w wyniku poronienia, „Civitas et Lex” 1 (2014), s. 27. 
tego, jakie miejsce w wieczności zajmują te dzieci. Stanowisko Kościoła w tej kwestii ewaluowało na przestrzeni dziejów. W dużej mierze było ono ukształtowane przez ojców Kościoła wschodniego i zachodniego.

Ojcowie Wschodu uważali, że odpowiedzialność za grzech można ponosić tylko poprzez czyn indywidualny. Nie można go zaciągnąć przez dziedziczenie. $Z$ tego powodu dzieci zmarłe bez chrztu, np. dzieci poronione i martwo urodzone, choć nie są godne chwały wiecznej, to jednak nie zasługują też na karę i na wieczne cierpienie. Jest też niemożliwe zbadanie tajemnic Bożych ${ }^{25}$.

Ojcowie Zachodu artykułowali bardziej radykalne stanowisko. Według nich każdy, kto nie przyjął chrztu jest skazany na wieczne potępienie. Ojcowie Zachodu podkreślali za św. Augustynem, że dzieci, które umarły bez chrztu skazane są na piekło. Pogląd ten został złagodzony dopiero w XIII wieku, kiedy zostało wprowadzone pojęcie limbus puerorum. Zdaniem twórców tej koncepcji, dzieciom zmarłym bez chrztu został wyznaczony oddzielny stan w życiu wiecznym, w którym nie doświadczają one żadnego cierpienia wewnętrznego ${ }^{26}$.

W powstałym w 1566 roku Katechizmie Rzymskim stwierdza się, że zaniedbanie chrztu skazuje dzieci na wieczny smutek i odłączenie ${ }^{27}$. Zmiany nastąpiły dopiero w nauczaniu Soboru Watykańskiego II, gdzie wspomniano o zbawczej woli Boga, która rozciąga się na wszystkich ludzi (1 Tm 2,4), także na dzieci nieochrzczone, które możemy jedynie polecać miłosierdziu Bożemu, ponieważ ich droga zbawienia jest sprawą Boga i nie może być przez nas określana (por. J. Ratzinger). Podkreśla to także Dokument Międzynarodowej Komisji Teologicznej pt. Nadzieja zbawienia dla dzieci, które umierają bez chrztu.

Katechizm Kościoła katolickiego określa to w następujących słowach:

25 Por. Międzynarodowa Komisja Teologiczna, Nadzieja zbawienia dla dzieci, które umieraja bez chrztu, tłum. J. Królikowski, Poznań 2008, nr 11.

26 Por. Międzynarodowa Komisja Teologiczna, Nadzieja zbawienia dla dzieci, nr 16 i 22, S. 10.

27 Por. Catechismus Romanus, II, 31 - cyt. za: M. Machinek MSF, Miejsce pośrednie? O wiecznym losie dzieci zmarłych bez chrztu, w: Od bólu po stracie do nadziei życia, s. 64 . 
Chrzest jest konieczny do zbawienia dla tych, którym była głoszona Ewangelia, i którzy mieli możliwość proszenia o ten sakrament [...]. Bóg związał zbawienie z sakramentem chrztu, ale sam nie jest związany swoimi sakramentami (KKK 1257).

Zdaniem Międzynarodowej Komisji Teologicznej problem dotyczy tego, jak zachować i pogodzić dwie grupy stwierdzeń biblijnych: tych, które odnoszą się do powszechnej woli zbawczej Boga (por. $1 \mathrm{Tm} 2,4$ ), i tych, które widzą w chrzcie środek konieczny do wyzwolenia z grzechu i upodobnienia do Chrystusa (por. Mk 16, 16; Mt 28, 18-19) ${ }^{28}$.

W kontekście dyskusji o losie dzieci, które umierają bez chrztu, tajemnica powszechnej woli zbawczej Boga jest podstawową i centralną zasadą. W deklaracji Dominus Iesus czytamy:

Należy więc stanowczo utrzymywać jako prawdę wiary katolickiej, że powszechna wola zbawcza Boga Trójjedynego została ofiarowana i spełniona raz na zawsze w tajemnicy wcielenia, śmierci i zmartwychwstania Syna Bożego ${ }^{29}$.

Do rozważanej tu kwestii można zastosować myśl kard. Josepha Ratzingera, który mówi:

Droga zbawienia dla dzieci, które umierają bez chrztu, jest sprawą Boga i nie może być przez nas określona. To Bóg lub Jego Duch Święty oferuje tym niemowlętom zbawienie, które musi być udziałem w wielkanocnym misterium krzyża i zmartwychwstania.

Ponieważ uważano, że to, co wyklucza te niemowlęta ze zbawienia, to brak chrztu, czy to in re, czy in voto, można również powołać się na doktrynę św. Tomasza z Akwinu, że Bóg nie wiązał swojej mocy z sakramentami w taki sposób, aby nie mógł nadać skutku sakramentowi bez sakramentu. Stosując to do przypadku dziecka, które umiera bez chrztu, możemy powiedzieć, że Bóg nie wiązał swojej mocy z sakramentem chrztu w taki sposób, aby nie mógł uwolnić niemowlęcia od odziedziczonej winy grzechu pierworodnego bez tego sakramentu ${ }^{30}$.

${ }_{28}$ Por. Międzynarodowa Komisja Teologiczna, Nadzieja zbawienia dla dzieci, nr 4.

${ }_{29}$ Kongregacja Nauki Wiary, Deklaracja „Dominus Iesus” o jedyności i powszechności zbawczejJezusa Chrystusa i Kościoła, Kraków 2000, nr 14.

30 Por. F.A. Sullivan SJ, The Development of Doctrine about Infants who die unbaptized, "Theological Studies" 72 (2011), s. 7. 
Dokument Międzynarodowej Komisji Teologicznej podkreśla, że

wiele czynników [...] daje poważne teologiczne i liturgiczne powody do tego, by mieć nadzieję, iż dzieci zmarłe bez chrztu będą zbawione i będą mogły cieszyć się wizją uszczęśliwiającą, przy czym „[...] chodzi tu o powody nadziei w modlitwie, a nie o elementy pewności”'31.

\section{Pogrzeb dziecka martwo urodzonego}

Kodeks Prawa Kanonicznego z 1917 roku zabraniał sprawiania liturgicznego pogrzebu dzieciom nieochrzczonym (kan. 1239), dlatego w praktyce duszpasterskiej miał miejsce obrzęd zwany potocznie pokropkiem. W ramach tego obrzędu odbywało się pokropienie trumny wodą i krótka modlitwa kapłana ${ }^{32}$.

Praktyka duszpasterska w zakresie pochówku dzieci zmarłych bez chrztu zmieniła się po Soborze Watykańskim II. W tym okresie dokonały się liczne zmiany w Kodeksie prawa kanonicznego i w tekstach liturgicznych. Nowy Kodeks prawa kanonicznego z 1983 roku usunął zapis obecny jeszcze w starym Kodeksie z 1917 roku o osobach zmarłych bez chrztu jako tych, którym należy odmówić pogrzebu kościelnego i pochówku w poświęconej ziemi (CIC, can. 1239 \$1) 33. W nowym KPK czytamy: „Ordynariusz miejsca może zezwolić na pogrzeb kościelny dzieci, których rodzice mieli zamiar je ochrzcić, a jednak zmarły przed chrztem" (kan. 1183). Ta norma prawa powszechnego została w Polsce uszczegółowiona przez Konferencję Episkopatu, zezwalającą „na katolicki pogrzeb dzieci, które zmarły przed chrztem, jeżeli rodzice pragnęli je ochrzcić”. Polecono też, aby przy tych pogrzebach były używane teksty przewidziane na pogrzeb dzieci nieochrzczonych ${ }^{34}$.

\footnotetext{
31 Międzynarodowa Komisja Teologiczna, Nadzieja zbawienia dla dzieci, nr 101.

32 Por. P. Guzdek, Rozpoznaj swoje dziecko we mnie. Rzecz o poronieniu samoistnym dziecka i jego pogrzebie, Kraków 2017, s. 383.

${ }_{33}$ Por. M. Ficoń, Los dzieci zmarłych bez chrztu - nieznana historia i współczesne pytania, „Polonia Sacra” 17 (2013) nr 1 (32), s. 128.

34 Por. Obrzędy pogrzebu dostosowane do zwyczajów diecezji polskich, Katowice 2014, nr 22e; U. Nowicka, Prawo do pochowania dziecka utraconego $w$ wyniku poronienia wedle ustawodawstwa polskiego i kanonicznego, „Łódzkie Studia Teologiczne” 26 (2017) nr 4, s. 156.
} 
Liturgia pogrzebowa i modlitwa wspólnoty chrześcijańskiej po śmierci dziecka bierze pod uwagę zarówno zmarłe dziecko, jak i dotkniętych żałobą rodziców. Za pomocą znaków wyraża ona zmiany w relacjach między tymi, którzy odchodzą, a pogrążonymi w żałobie, jak i pomiędzy samymi żałobnikami i ich otoczeniem ${ }^{35}$. W Obrzędach pogrzebu dostosowanych do zwyczajów diecezji polskich opisane zostały trzy formuły liturgii pogrzebu dziecka nieochrzczonego. W czasie sprawowania Eucharystii używa się białych szat liturgicznych, co jest widocznym znakiem niewinności dziecka ${ }^{36}$.

Celebracja Eucharystii powinna być czasem anamnesis, kiedy łączymy nasze obecne cierpienie z cierpieniem Chrystusa i całą historią ludzkiego cierpienia $^{37}$. Sytuacja rodziców po stracie dziecka martwo urodzonego może przypominać sytuację Hioba, który cierpiał będąc człowiekiem sprawiedliwym. Dziecko poronione, bądź to, które zmarło zaraz po porodzie było bez grzechu, niewinne. Eucharystia nie jest nawet sprawowana w intencji odpuszczenia jego grzechów, ale za obecnych na liturgii. Ona ma napełnić obecnych nadzieją mimo cierpienia, którego doświadczają i często nie potrafią zrozumieć jego sensu.

Liturgia podkreśla, że Chrystus jest Pocieszycielem strapionych. Przychodzi, by dodać otuchy tym, którzy są przygnębieni z powodu bólu (Mt 9, 2. 22) $)^{38}$. Jest źródłem wszelkiej pociechy zwłaszcza dla tych, którzy czują się oddzieleni przez śmierć od drogich im istot (1 Tes 4, 18). To pocieszenie nie kończy się z chwilą Jego odejścia do Ojca. Jezus nie opuszcza swoich uczniów. Duch Święty, który został im dany, nie przestaje obdarzać społeczności chrześcijańskiej wewnętrznym pokrzepieniem,

35 Por. J. Dziedzic, Wsparcie psychologiczno-pastoralne w przeżywaniu żałoby po stracie dziecka, w: Od bólu po stracie do nadziei życia, s.168.

36 Por. P. Majer, Kilka uwag na temat pogrzebu dzieci, w: Poronienie. Zrozumieć rodziców po stracie, red. C. Klahs, Poznań 2010, s. 233.

37 Por. V. McCracken, Preaching lament, ,Restoration Quarterly” 44 (2002) Issue 4, s. 212;

38 H. Sławiński, Homilia podczas pogrzebu dzieci zmarłych bez chrztu, w: Od bólu po stracie do nadziei życia, s. 150-151; H. Sławiński, Duszpasterska opieka i głoszenie Dobrej Nowiny Chrystusa rodzicom dzieci zmartych przed urodzeniem, „Polonia Sacra” 37 (2014) nr 4, s. 141-157. 
co umożliwia jej wytrwanie wśród trudności (Dz 9, 31) $)^{39}$. Papież Franciszek podkreśla, że

chrześcijanin wie, iż nie da się wyeliminować cierpienia, ale może ono nabrać sensu, może stać się aktem miłości, powierzeniem się w ręce Boga, który nas nie opuszcza, i tym samym być etapem wzrostu wiary i miłości ${ }^{40}$.

\section{Towarzyszenie osieroconym po śmierci dziecka}

Żałoba jest naturalną i normalną reakcją na traumatyczne wydarzenie, jakim jest śmierć. Nie jest ona chorobą, choć dotyka sfery fizycznej, psychicznej i duchowej. Osobom przeżywającym żałobę po stracie dziecka potrzebne jest wsparcie. Przepracowanie żałoby jest bowiem złożonym i rozciągniętym w czasie doświadczeniem, składającym się z różnych reakcji, doznań i zachowań, takich jak: rozpacz, smutek, niepokój, niedowierzanie, poczucie winy, osamotnienie, a nawet utrata sensu życia ${ }^{41}$.

Osoby wierzące przeżywające żałobę po stracie dziecka szukają często pocieszenia ze strony wspólnoty parafialnej. Pocieszenie strapionych należy do podstawowych zadań ludzi wierzących. Wagę pocieszenia bardzo dobrze przedstawił św. Paweł, który pisze to Tesaloniczan: „Sam zaś Pan nasz Jezus Chrystus i Bóg, Ojciec nasz, który nas umiłował i przez łaskę udzielił nam niekończącego się pocieszenia i dobrej nadziei, niech pocieszy serca wasze i niech utwierdzi was we wszelkim czynie i dobrej mowie” (2 Tes 2, 16-17). Zdaniem św. Pawła, „kto czuje się pocieszony przez Boga, ten jest w stanie pocieszać innych" (por. 2 Kor 1,4$)^{42}$.

39 Por. Słownik teologii biblijnej, red. X. Léon-Dufour, Poznań 1990, s. 691; K.E. Apfelbacher, Selig die Trauernden. Kulturgeschichtliche Aspekte des Christentums, Regensburg 2002, s. 106-108.

$40 \quad$ Franciszek, Encyklika Lumen fidei, Poznań 2013, nr 56.

41 M. Ryś, Psychologia małżeństwa w zarysie, Warszawa 1999, s. 89.

42 Por. J. Dziedzic, Wsparcie psychologiczno-pastoralne w przeżywaniu żałoby po stracie dziecka, w: Od bólu po stracie do nadziei życia, s. 166. 


\section{W kontekście pocieszenia papież Franciszek zachęca:}

Każdy chrześcijanin, a zwłaszcza kapłani są powołani, by nieść orędzie nadziei, które daje pokój ducha i radość: pocieszenie Boga, Jego czułość wobec wszystkich. Jest to ważne, aby nasza misja była owocna: odczuwać Boże pocieszenie i przekazywać je. Zachęta Izajasza musi rozbrzmiewać w naszym sercu: „Pocieszcie, pocieszcie mój lud!" (Iz 40, 1) $)^{43}$.

Do istoty pocieszenia należy nawiązanie relacji z osieroconym. Pomagający powinien przede wszystkim być obecny przy osieroconym, umieć słuchać i zaakceptować go takim, jakim on jest w danym momencie. Obecność u boku osoby cierpiącej jest darem. Wyraża się ona w skupieniu uwagi na problemie osoby strapionej, w bliskości fizycznej, modlitwie, we wspierającym geście. Kontakt z przeżywającym żałobę można realizować na wiele sposobów. Może to być wizyta, spacer czy rozmowa telefoniczna. Ważne jest niekiedy wysłanie SMS-a i napisanie listu ${ }^{44}$. Cenna wydaje się być empatia, a także milczące współtowarzyszenie z osobą, która cierpi. Towarzyszenie w żałobie winno być podjęte przez całą społeczność. Nie może ograniczyć się ono jedynie do rodziny, krewnych lub przyjaciół ${ }^{45}$. Rzeczywista pomoc wiąże się z unikaniem błędów w postaci sloganów, wmawiania, że nic się nie stało, obojętności czy agresji ${ }^{46}$.

Osobie w żałobie należy pomagać na wszystkich jej etapach. W początkowych fazach otoczenie powinno pomóc osieroconemu przy wykonywaniu codziennych obowiązków, aby mógł on zdobyć przekonanie, że nie jest sam. Ponieważ żałobnik musi dalej samodzielnie żyć, okazywana mu pomoc nie powinna być zbyt daleko idąca. W fazie, kiedy pojawiają się intensywne emocje, ważna jest zarówno obecność przy osieroconym, jak i aktywne słuchanie, a także wczuwanie się w przeżycia doświadczane przez żałobnika. Aby móc skutecznie przepracować żałobę, należy

43 Franciszek, Homilia do seminarzystów, nowicjuszy i nowicjuszek, 7.07.2013, http://www. mojepowolanie.pl/1702,a,homilia-papieza-franciszka-wygloszona-do-seminarzystow-nowicjuszy.htm (2.11.2020).

44 Por. J. Dziedzic, Wsparcie psychologiczno-pastoralne w przeżywaniu żałoby po stracie dziecka, w: Od bólu po stracie do nadziei życia, s. 161.

45 Por. W. Haunerland, Das Begräbnis - eine wichtige pastorale Chance?, „Pastoralblatt” 10 (2003), s. 302-308.

46 U. Dudziak, Sytuacja rodziców doświadczających śmierci dziecka przed urodzeniem, w: Od bólu po stracie do nadziei życia, s. 176. 
cierpliwie zaakceptować wyraziste emocje. Ich odreagowanie pozwala powrócić do stabilnego życia. W emocjonalnym chaosie znika to, co stare i tworzy się to, co nowe ${ }^{47}$.

Pomoc rodzicom w żałobie jest niezbędnym zadaniem duszpasterskim. Wymaga ono solidarności w cierpieniu. Wsparcie rodziców w sytuacji straty dziecka jest dużym wyzwaniem. Motyw chrześcijańskiej pomocy osieroconym jest zawsze podwójny: wyjść naprzeciw żałobie ludzi poszukujących pocieszenia, które ostatecznie pochodzi od Boga oraz przekazywać Boże miłosierdzie strapionemu człowiekowi. Chodzi o postawę miłości,

aby dostrzec obok siebie brata, który [...] doznaje poczucia opuszczenia, zagubienia i beznadziei. Potrzeba „wyobraźni miłosierdzia”, aby [...] nieść radę, pocieszenie, duchowe i moralne oraz wsparcie tym, którzy podejmują wewnętrzną walkę ze złem ${ }^{48}$.

Wsparcie żałobników przez wspólnotę parafialną winna być troską wyrażającą się w posłudze miłości, dlatego też zrozumiałe staje się pocieszenie, jako chrześcijańskie zadanie wynikające z wiary, która ma swoje zakorzenienie „w Bogu wszelkiej pociechy” (2 Kor 1,3).

\section{Zakończenie}

Strata dziecka przed porodem jest bardzo trudnym doświadczeniem. Dotyka ona nie tylko kobietę, ale całą jej rodzinę. Nagle bowiem pełne nadziei oczekiwanie na przyjście kogoś, kto ma się stać projektem przyszłości, zmienia się w smutek, a nawet rozpacz postrzegający martwe urodzenie dziecka jak porażkę.

Przeżywana żałoba po takiej stracie jest niekiedy bardzo intensywna i wymaga wsparcia nie tylko bliskich, ale także terapeutów i duszpasterzy. Ważna jest obecność, aktywne słuchanie oraz gotowość do każdego

47 Por. T. Schnelzer, „Die Liebe hört niemals auf” (1 Kor 13,8). Religionspsychologische und theologische Aspekte des Trauerprozesses, „Lebendiges Zeugnis” 57 (2002), s. 207-209.

${ }_{48}$ Por. Jan Paweł II, Homilia wygłoszona 18 sierpnia 2002 w czasie Mszy beatyfikacyjnej na krakowskich Błoniach, http://www.ojczyzna.pl/Arch-Teksty/JPII_HOMILIA_JPII_Blonia_18-08-02.htm (2.11.2020). 
gestu życzliwej pomocy. Dla rodziców wierzących istotna jest organizacja pogrzebu dla martwo urodzonego dziecka. Jest on możliwy także dla dziecka nieochrzczonego. Używane biały szaty liturgiczne w czasie Mszy Świętej podkreślają niewinność dziecka. Rodzice mogą też mieć nadzieję, że jest ono zbawione, ponieważ Bóg nie jest związany sakramentami i „pragnie, żeby wszyscy ludzie zostali zbawieni” (1 Tym 2, 4).

Należy żywić nadzieję, że zaprezentowany artykuł pomoże czytelnikowi głębiej zrozumieć problem straty dziecka martwo urodzonego. Jest on bowiem wielowymiarowy i obejmuje szereg kwestii z obszaru medycyny, psychologii, prawa, ale także i teologii. Podjęty w artykule aspekt pastoralny ma pomóc duszpasterzom w szerszy sposób, uwzględniający inne dyscypliny, z których korzysta teologia praktyczna, zgłębić tę trudną i aktualną problematykę dotyczącą początków ludzkiego życia i śmierci.

\section{Bibliografia}

Apfelbacher K.E., Selig die Trauernden. Kulturgeschichtliche Aspekte des Christentums, Regensburg 2002.

Bansen S.S., Stevens HA. Women's experiences of miscarriage in early pregnancy. ,Journal of Nurse Midwifery" 37 (1992), s. 84-90.

Biesaga T., Spór o moralny status człowieka w okresie prenatalnym, „Medycyna Praktyczna - Ginekologia i Położnictwo" 6 (2006), s. 1-5.

Bremer J., Szacunek wobec ludzkich zwłok. Spojrzenie filozoficzno-prawne, w: Pedagogiczna refleksja nad życiem i śmiercia, red. B. Grochmal-Bach, Kraków 2013, https:// opoka.org.pl/biblioteka/I/ID/wam_2013_smierc_01.html (3.11.2020).

Brier N. Understanding and managing the emotional reactions to a miscarriage, „Obstetrics Gynecology" 93(1999), s. 151-155.

Bubiak A., Bartnicki J., Knihinicka-Mercik Z., Psychologiczne aspekty utraty dziecka w okresie prenatalnym, „Pielęgniarstwo i Zdrowie Publiczne” 4 (2014) nr 1, s. 69-78.

Clark Miller S., The Moral Meanings of Miscarriage, "Journal of Social Philosophy" 46 (2015) Issue 1, s. 141-157.

DiMarco M., Renker P., Medas J., Bertosa H., Goranitis J.L., Effects of an Educational Bereavement Program on Health Care Professionals' Perceptions of Perinatal Loss, "Journal of Continuing Education in Nursing" 33 (2002) Issue 4, s. 180-186.

Dudziak U., Sytuacja rodziców doświadczających śmierci dziecka przed urodzeniem, w: Od bólu po stracie do nadziei życia. Pogrzeb dziecka poronionego, red. J. Dziedzic, P. Guzdek, Kraków 2013, s.175-198.

Dziedzic J., Beistand bei Trauer. Psychologisch-pastorale Aspekte, „Polonia Sacra” 18 (2014) nr 2 (35), s. 51-74. 
Dziedzic J., Wsparcie psychologiczno-pastoralne w przeżywaniu żałoby po stracie dziecka, w: Od bólu po stracie do nadziei życia. Pogrzeb dziecka poronionego, red. J. Dziedzic, P. Guzdek, Kraków 2013, s. 153-173.

Dziedzic J., Żałoba po śmierci Jana Pawła II. Analiza ilościowo-jakościowa Księgi kondolencyjnej. Internauci w hołdzie papieżowi Janowi Pawłowi II, Kraków 2009.

Dziewiecki M., Jak wspierać matkę po poronieniu dziecka?, https://glosdlazycia.pl/ wydanie/w-numerze/jak-wspierac-matke-po-poronieniu-dziecka/ Głos dla Życia 2011/6, s. $16(3.11 .2020)$.

Ficoń M., Los dzieci zmarlych bez chrztu - nieznana historia i wspótczesne pytania, „Polonia Sacra" 17 (2013) nr 1 (32), s. 111-133.

Franciszek, Homilia do seminarzystów, nowicjuszy i nowicjuszek, 7.07.2013, http:// www.mojepowolanie.pl/1702,a,homilia-papieza-franciszka-wygloszona-do-seminarzystow-nowicjuszy.htm (2.11.2020).

Franciszek, Encyklika Lumen fidei, Poznań 2013.

Guzdek P., Rozpoznaj swoje dziecko we mnie. Rzecz o poronieniu samoistnym dziecka i jego pogrzebie, Kraków 2017.

Guzewicz M., Psychologiczne i społeczne konsekwencje utraty dziecka w wyniku poronienia, „Civitas et Lex” 1 (2014), s. 15-27.

Haunerland W., Das Begräbnis - eine wichtige pastorale Chance?, „Pastoralblatt” 10 (2003), s. 302-308.

Jan Paweł II, Homilia wygłoszona 18 sierpnia 2002 w czasie Mszy beatyfikacyjnej na krakowskich Błoniach, http://www.ojczyzna.pl/Arch-Teksty/JPII_HOMILIA_JPII_Blonia_18-08-02.htm (2.11.2020).

Kongregacja Nauki Wiary, Donum vitae, Instrukcja o szacunku dla rodzącego się życia ludzkiego i godności jego przekazywania, 22.02.1987, nr 1, 4, w: W trosce o życie. Wybrane dokumenty Stolicy Apostolskiej, red. K. Szczygieł, Biblos, Tarnów 1998, s. 360-385.

Kongregacja Nauki Wiary, Deklaracja „Dominus Iesus” o jedyności i powszechności zbawczej Jezusa Chrystusa i Kościoła, Kraków 2000.

Lothrop H., Gute Hoffnung, jähes Ende, München 2016.

Machinek M. MSF, Miejsce pośrednie? O wiecznym losie dzieci zmarlych bez chrztu, w: Od bólu po stracie do nadziei życia. Pogrzeb dziecka poronionego, red. J. Dziedzic, P. Guzdek, Kraków 2013, s. 59-72.

Majer P., Kilka uwag na temat pogrzebu dzieci, w: Poronienie. Zrozumieć rodziców po stracie, red. C. Klahs, Poznań 2010, s. 231-236.

McCracken V., Preaching lament, „Restoration Quarterly” 44 (2002) Issue 4, s. 205-216.

Meller J., Moralny aspekt wykorzystania zwłok ludzkich, „Studia Gdańskie” 21 (2007), s. 427-440.

Międzynarodowa Komisja Teologiczna, Nadzieja zbawienia dla dzieci, które umieraja bez chrztu, Poznań 2008.

Nowicka U., Prawo do pochowania dziecka utraconego w wyniku poronienia wedle ustawodawstwa polskiego i kanonicznego, „Eódzkie Studia Teologiczne” 26 (2017) nr 4, s. $147-159$. 
Obrzędy pogrzebu dostosowane do zwyczajów diecezji polskich, Katowice 2014.

Papieska Rada do spraw Duszpasterstwa Służby Zdrowia, Karcie Pracowników Służby Zdrowia, Watykan 1995, nr 146, w: W trosce o życie. Wybrane dokumenty Stolicy Apostolskiej, red. K. Szczygieł, Tarnów 1998, s. 549-627.

Ryś M., Psychologia małżeństwa w zarysie, Warszawa 1999.

Schnelzer T., „Die Liebe hört niemals auf” (1 Kor 13,8). Religionspsychologische und theologische Aspekte des Trauerprozesses, „Lebendiges Zeugnis” 57(2002), s. 207-209.

Sławiński H., Duszpasterska opieka i głoszenie Dobrej Nowiny Chrystusa rodzicom dzieci zmarlych przed urodzeniem, „Polonia Sacra” 37 (2014) nr 4, s. 141-157.

Sławiński H., Homilia podczas pogrzebu dzieci zmarłych bez chrztu, w: Od bólu po stracie do nadziei życia. Pogrzeb dziecka poronionego, red. ks. J. Dziedzic, P. Guzdek, Kraków 2013, s. 127-152.

Słownik teologii biblijnej, red. X. Léon-Dufour, Poznań 1990.

Sullivan, S.J, The Development of Doctrine about Infants who die unbaptized, „Theological Studies" 72(2011), s. 3-14.

Thompson J.A., Making room for the other: maternal mourning and eschatological hope, „Modern Theology” 27 (2011) Issue 3, s. 395-413.

Worden J.W., Beratung und Therapie in Trauerfallen, Bern, 1986/1999.

Załącznik nr 1 do rozporządzenia Ministra Zdrowia z dnia 6 kwietnia 2020 w sprawie rodzajów, zakresu i wzorów dokumentacji medycznej oraz sposobu jej przetwarzania (Dz. U. z 2020, poz. 666). 